\title{
Ezek a mai fiatalok! Ezek a mai fiatalok?
}

Howard Gardner - Katie Davis (2014): The App Generation - How Today's Youth Navigate Identity, Intimacy and Imagination in a Digital World c. könyve

$\mathbf{M}$

Á

C

I

ó

S

$\mathbf{T}$

Á

$\mathbf{R}$

S

A

D

Így hivatkozzon erre a cikkre:

Komár Zita. „Ezek a mai fiatalok! Ezek a mai fiatalok?”.

Információs Társadalom XV, 2. szám (2015): 96-101.

$=\quad h t t p s: / / d x . d o i . o r g / 10.22503 /$ inftars.XV.2015.2.9

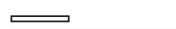

A folyóiratban közölt müvek

a Creative Commons Nevezd meg! - Ne add el! - Így add tovább! 4.0

Nemzetközi Licenc feltételeinek megfelelöen használhatók. 


\title{
Komár Zita
}

\section{Ezek a mai fiatalok! Ezek a mai fiatalok?}

\author{
A The App Generation - How Today's Youth Navigate Identity, Intimacy \\ and Imagination in a Digital World címú könyv recenziója ${ }^{1}$
}

Howard Gardner és Katie Davis könyvükben az általuk app-generációnak nevezett korosztállyal foglalkoznak, elsôsorban a pszichológiai tényezók és a (modern) technika viszonylatában igyekeznek új, eddig ki nem mondott hipotéziseket megfogalmazni. Az app-generáció fogalma arra utal, hogy a szerzópáros megközelítése szerint az applikációk a mostani fiatalokra leginkább számottevố hatással bíró kulturális jelenségek. Könyvükben ezt a tézisüket fejtik ki részletesebben.

Saját kutatásaik ismertetése mellett a szerzók körbejárják a XX. század (és egy-egy fejezet erejéig, az azt megelőzó korszakok) technikai újításainak emberi természetre gyakorolt hatásait, bevonva az elemzésbe ismert pszichológia- és viselkedéstudományi iskolák elméleteit, valamint a társadalomtudományok - és egyben a kommunikációtudomány -, nagyjainak releváns munkásságát is. Gardner és Davis alapvetốen egy kismintás kvalitatív kutatásra alapozzák feltáró jellegú megállapításaikat². Az olvasó egy beszélgetéseken, és minôségi visszajelzéseken alapuló összeállítással találkozik (mely valóban egy interperszonális találkozás). Ezt a feltáró kutatást egészítik ki saját, az amerikai középosztálybeli miliő tagjaival lefolytatott kvantitatív és kvalitatív kutatásaik, valamint érdekes és egyedi példák sokasága. Az újító szándék leginkább a választott módszertan, valamint az értelmezési keret, ezen belül is, a fókuszpontok kijelölése során mutatkozik meg: Gardner és Davis az identitás, intimitás és imagináció (vagy más néven képzelőerố) hármas kontextusában értelmezi a megfigyelt jelenségeket, melyek a fiatal generációk önmeghatározását, másokkal szembeni viselkedését és jövóképét alkotó, konstitutív elemekként tételeződnek. A szerzốpáros tehát sokkal inkább kínál egy izgalmas, újszerú pszichológiai elemzésen alapuló értelmezést (még ha elsố ránézésre nem is ezt sugallja a könyv), semmint technika- vagy fejlődéstörténeti látképet - ezek a kísérletek ugyanis marginálisak maradnak a választott társadalmi-szociálpszichológiai elméleti háttérben, amely azonban inkább elónyére válik a múnek, semmint hátrányára.

\footnotetext{
${ }^{1}$ Howard Gardner - Katie Davis (2014): The App Generation - How Today's Youth Navigate Identity, Intimacy and Imagination in a Digital World. Yale University Press; Reprint edition

${ }^{2} 2008$ és 2010 között, a szerzók szisztematikus interjúkat készítettek kb. 150, New England térségben élố fiatallal, arra fókuszálva, mit gondolnak a fiatalok a digitális médiáról és hogyan használják annak elemeit önkifejezésük és kapcsolattartási szokásaik során. Ezt egészíti ki egy, a témában széles körú ismeretekkel rendelkezó felnốttekkel végzett kutatás ( 7 fókuszcsoport, 6-10 résztvevốvel, akik valamilyen formában, fiatalokkal dolgoztak az elmúlt 20 évben). A szerzók vizsgálódásaik során egy további összetevốvel egészítik ki az elemzést: a fiatalok, jellemzóen diákok múvészi produkciói egy 20 éves perióduson belül kerülnek összevetésre (melyek a volt és jelenlegi diákok anyagait tartalmazó raktárakból kerültek eló). A diákok írásainak és grafikus termékeinek létrehozása során, ezen periódus alatt végbement változások megfigyelése, felhívja a figyelmet a fiatalok által (ön)kifejezésre választott médiumok fontosságára és az e téren bekövetkezố változásokra.
} 
A digitális média és a digitális média korában felnốtt generáció megismerésének kulcsfogalmát a szerzók az applikációban találták meg. A szerzópáros érvelése szerint, egy app lehet hasznos vagy éppen támogató, ha segít minket mindennapi ügyeink intézésében, ha megkönnyíti életünket és megoldásokat kínál apró-cseprô problémáinkra (app-enabling). Azonban ha applikációink eluralkodnak rajtunk és pusztán fogyasztókká degradálnak minket, olyan szerves organizmusokká, akik nem képesek önmagukról és az óket körülvevố világról önállóan gondolkodni, akkor az app-evolúció csupán modern rabszolgaságba hajtja alkalmazóját (app-dependent).

A szerzók a legifjabb generációk képviselóinek megértéséhez két diszciplináris kontextust javasolnak: a technológiai kontextus (az általuk választott technológiák alapján próbáljuk megérteni óket), illetve a diszciplináris kontextust (a biológiai meghatározottság helyett immár azok tartoznak egy generációba, akik egy nagy közös élményen osztoznak). ${ }^{3}$ A következóben ezt a két kontextust vizsgáljuk meg részletesebben.

\section{Technológiai kontextus}

A digitális világ megjelenése számos új szokás kialakulásával jár, mely alapján, két-féle embertípus és applikáció-csoport különíthetô el (megjegyezve, hogy a legtöbb emberi ágens a kettố között oszcillál):

1. azok az applikációk, amelyek diktálják a cselekvéseket (függóség) és azok az individuumok, akik vállalják ezt a függóséget (hagyománykövetók);

2. azok az applikációk, amelyek felfedezố-típusúak, ily módon kinyitják a cselekvési horizontot (feljogosítva a felhasználót), és azok az újító individuumok, akik elutasítják szokásosat és az egyéni irányítást lehetôvé tevớ kondíciókat keresnek.

Mindez az identitás, intimitás, imagináció szintjére vetítve, a következố lehetôségeket rajzolja ki:

1. identitás kialakítása: az applikációk lerövidíthetik az identitásalkotási folyamatot (pl. avatarok létrehozása), melynek révén kétféle kimenetel lehetséges: az individuum egy megerósödött énképpel rendelkezik, vagy ellenkezó esetben, betagozódik egy eloóre gyártott identitás alá (ebben az esetben az app uralkodik az egyén felett);

2. intimitás: az applikációk bátoríthatják a szemtốl-szembeni konfrontációt és interakciót (feltételve, hogy minden emberi reakció besorolható, sốt, elôre megjósolható) vagy még tágabbra nyithatják a világot az egyén számára, új utakat biztosítva mások megismeréséhez (ebben az esetben az egyén uralja az applikációt);

3. imagináció: az applikációk adott esetben, lustává tehetnek, megakadályozhatják új készségek elsajátítását, ugyanakkor egy új világot tárhatnak fel; a képzelet, az alkotás és a termelés világát, mely az identitásképzés és az intimitás új, gazdag formáit hordozza.

${ }^{3}$ Ezzel egy idóben, említésre kerülnek az elmúlt fél évszázad politikai, társadalmi eseményei is különös tekintettel azok, amelyek meghatározzák az identitás, az intimitás és imagináció társas kontextusait a különbözó generációk számára - Gardner és Davis ezáltal képesek egy generációkon átívelő összehasonlítást végrehajtani és a jövốre vonatkozó kérdéseket megfogalmazni. 


\section{Diszciplináris kontextus}

A szociológiai megközelítés szerint az egy generációba tartozók nem a lakóhelyükben, vagy felmenóikben, hanem élményeikben osztoznak (jó példa erre az elsô világháborút átélt, ún. „elveszett generáció”). A digitális technológia tehát nem csupán a már meglévố viszonyokat rendezi át, de egyben egy újfajta generáció kialakulását is eredményezi.

Gardner és Davis a kognitív kapacitásra fókuszál, ez feljogosítja az individuumot, hogy újfajta módokon cselekedjen és gondolkodjon - s ezeket képzelóerónek (imaginative powers) nevezik. Ha jobban megvizsgáljuk ezt a kognitív kapacitást, akkor arra az eredményre jutunk - érvelnek Gardnerék -, hogy egyre több fiatal válik app-függóvé ahelyett, hogy app-irányítóvá válna. Amíg tehát a generációkat konstituáló, közös élmények korábban politikai vagy társadalmi eseményekhez kötôdtek, addig ma az élményeket az internet és okos készülékeink szúrik és definiálják, így a közös tapasztalatok alapjai a web és okostelefonok lesznek, valamint az olyan közösségi oldalak, mint pl. a Facebook. Ha viszont, a fiatalok magukat a legújabb, legdivatosabb technológiai eredmények részének tekintik, és ezek függvényében alkotják meg énképüket, talán érdemesebb volna a generáció definícióját újra gondolni.

Létezik biológiai, politikai, kulturális, társadalmi és technológiai értelemben vett generáció, a lehetséges keveredésekkel együtt (pl. elképzelhetó, hogy két, három vagy több generáció él egy fedél alatt, miközben a technológiához való viszonyuk nagyon is különbözố). A legutóbbi évtized generációja, a digitális vagy web generáció kifejezés azonban félrevezetố módon, csupán a technológiai tényezốre fókuszál. Így aztán az app-generáció kifejezéssel e mögé nézve, a szerzók képessé válnak a technológiai kontextus mellé beemelni a pszichológiai tényezót is: megragadva a kognitív, társadalmi, emocionális és etikai dimenzióit annak, mit is jelent fiatalnak lenni a XX-XXI. században.

\section{Identitás vagy app-dentitás}

Egy app vagy applikáció nem más, mint felhasználójának ujjlenyomata: érdeklódési körének, szokásainak és szociális kapcsolatainak kombinációja. Az app-identitás több irányból fazettált, magasan perszonalizált, kifelé-tekintố és erôsen szúkített. A szerzôpáros hipotézise szerint, a fiatalok identitása egyre inkább elóre gyártottá válik, melynek eredménye a belsố életre irányuló fókusz minimalizálása és a kockázatvállalási készség csökkenése, ugyanakkor pozitív hatása az elfogadott önkifejezési módok szélesedése és bôvülése. A digitális média hatására, a fiatalok (ön)kifejezéshez használt eszközeinek és kontextusainak túltengése figyelhetố meg, melyek az identitással való játék és a próbálgatás szabad terepei. De vajon az applikációk bátorítják vagy korlátozzák az identitás kifejezését?

Hogy megválaszolhassuk a kérdést, elóbb az identitás-termelés és az autentikus identitás kialakításának lehetôségeit kell körbejárnunk. Az identitás ma sokkal inkább kifelé orientált, mint korábban, ennek következtében ez a generáció jellemzóen karrier- és témaorientált, illetve inkább pragmatikus, semmint ideologikus (azaz tagjai a mindennapi élet feladataira fókuszálnak a hosszú-távú problémák és megoldások helyett). Mindez egy szélesebb társadalmi tendenciába illeszkedik: az individualizmus elớretörése a közösséget középpontba helyezố, intézményi orientáció helyett, egyfajta mások által való vezéreltséget fémjelez (other-directedness), amely szorosan kapcsolódik az önmagukra irányuló erôs 
fókusz megjelenéséhez és ezzel párhuzamosan, az individuális értékek eloore töréséhez - e kettố pedig a médiaplatformokon találkozik. Ahogyan egy applikáció attraktivitása is sokkal inkább externális kiterjesztésein múlik, semmint belsố értelemben vett funkcionalitásán, az app-piac is végtelen lehetôséget biztosít a fiatalok számára digitális élményeik perszonalizációjára, mely így sokkal inkább külsó fókuszt nyer, s így nem támogatja az autonóm identitás kialakítását. Ugyanakkor pozitív következménye, hogy a mai fiatalok sokkal nyitottabbak lettek a különbözó identitások irányába és megértóbbek/elfogadóbbak azokkal szemben, amelyek távol állnak tólük (bár ez nem mindig jár együtt ezen különbségek forrásának megértésével).

\section{APPvolúció}

Az applikációk újradefiniálták, mit jelent másokkal kapcsolatba lépni és elérni valakit, mely még sosem volt egyszerúbb, mint manapság. Ugyanakkor kapcsolataink minôsége ma leginkább attól függ, hogy arra használjuk-e az applikációkat, hogy elkerüljük a kényelmetlen helyzeteket és kellemetlen érzéseket, amik azzal járnak, hogy kapcsolatban állunk egymással, vagy vállaljuk a kockázatot, a tartalmas interakciók kialakítása érdekében. A leginkább szembetúnó változás azonban a kommunikáció folyamatos jelenlevôsége és azonnalisága. A szerzók kutatásai eredményeiból az derül ki, hogy az amerikaiak kimutathatóan magányosabbak és szociális értelemben elszigeteltebbek lettek az elmúlt ötven évben. De hogyan lehetséges, hogy azok a közösségi oldalak, amelyeket az emberek összekötésére hoztak létre, csak még magányosabbá tették óket? A tendenciával szembe menve, egyes fiatalok a valós, szemtól-szembeni kapcsolatok helyettesítése helyett, azok növelésére használják az online kommunikációt (stimuláló hatás). Ezen hatások nagy része (pozitív vagy negatív) azonban a fiatalok technológiához való hozzáállásán múlik, nem az egyes alkalmazásokon. Az app tehát valóban egy rövidítés; egy rövidebb út a sok közül, amelyek célja, hogy a másokkal való kapcsolattartást egyszerúbbé, gyorsabbá és kevésbé kockázatossá tegye számunkra, ugyanakkor fontos megemlíteni, hogy ebben a túl-stimulált világban, ezek a tendenciák nem csupán az individuumokra, de szélesebb társadalomi környezetükre is hatással vannak (pl. az empátia hiánya vagy a búnözés növekedése következhet a másság szélesebb körú elfogadásából is).

Az applikációk megváltoztatták a fiatalok (ön)kifejezési módjait, új utakat nyitva meg, melyek olcsóbb, gyorsabb, könnyebb elérhetôséget és közönséget biztosítanak a felhasználók számára, újradefiniálva kiból lehet alkotó és mi számít alkotásnak. Az applikációk legfontosabb hatása az átható/átjáró jelleg, egyfajta kapuként múködnek. Gardner és Davis kutatásaikban (1990-2011) egyebek mellett azt vizsgálták, a fiatalok hogyan használják kognitív, szociális és emocionális képességeiket megértésük kiszélesítésére és egyéni produkcióik gazdagítására (ez az ún. think outside the box mentalitás). ${ }^{4}$ Összességében

\footnotetext{
${ }^{4}$ Elemzéseik során, megfigyelték, hogy az elmúlt évtizedekhez képest, a múalkotások komplexebbek lettek, a fiatalokra egyre kevésbé jellemzô a konvencionális ábrázolás, s míg a digitális úton manipulált produkciók száma erôsen megnövekedett, azok annál kevésbé fantáziadús vagy valóságtól elrugaszkodott elemeket tartalmaznak, sokkal inkább az „evilági” összetevók dominálnak bennük, míg a prózai múvek történetvezetése jellemzốen lineáris és ismerốs elemeket tartalmaz, formális nyelvi elemek pedig egyre kisebb számban jelennek meg.
} 
elmondható, hogy míg a vizuális múvészet kevésbé konvencionálissá vált, addig a kreatív írás annál inkább az lett. Ez összecseng azzal, hogy a megkérdezett tanárok és táborvezetók szerint, ma a diákok sokkal kevésbé képesek saját ötletekkel elójönni (hiszen az internet az ötletek bóséges tárházát kínálja nekik/helyettük), és éppen ezért, az app-generáció tagjai kevésbé kockázatvállalóak, mint az elốzó generációk.

Van azonban, ami optimizmusra adhat okot: a különféle applikációk egyúttal több lehetôséget is biztosítanak a fiatalok számára és az online jelenlét bizonyos formái (pl. a videojátékok) ösztönzố hatással lehetnek a kreativitásra: a digitális eszközök támogatást nyújthatnak és elôsegíthetik az együttmúködést (mely utóbbi elsôdleges fontosságú a kreatív gondolkodás és feladat-végrehajtás szempontjából). Nehéz (ha nem lehetetlen) azonban annak elkülönítése, hogy mi számít elsố lökésnek és mikor van az, amikor már egy elốre gyártott ötlet „másolatával” van dolgunk?

Talán védhetônek az álláspont, miszerint mindennapi életünk során szükség van bizonyos mértékú automatizáltságra, de vajon mindent automatizálni kell-e? Ki dönti el mi fontos? Hol van a határ a kivitelezés és a tartalom között, amit a kivitelezés során megvalósítunk? Mindezen kérdések, érzésem szerint nem kerültek kellô mértékben meghatározásra vagy tárgyalásra a kötetben, ugyanakkor így is izgalmas volt egy olyan munkával találkozni, amely egy lépést hátralépve igyekszik szemlélni generációs és technológiai öszszefonódásokat. A szerzópáros értelmezése kritikai szögból veszi szemügyre az app-generációt körüllengó misztikumot és számadatolást, anélkül, hogy elốitéleteket vagy puszta adatelemzést tartalmazna. Mindaz, amit a szerzók elénk tárnak egy, ha nem is vegytiszta, de világos célkitûzések, vizsgálati anyag és eredmények mentén megfogalmazott elemzés, melynek során (végül még a vallás, az etika és az oktatás területei is megjelennek a tárgyalási univerzumban), eljutunk egy következó, ha nem is az utolsó lépcsófokra, ahonnan szélesebb rálátásunk nyílik az említett folyamatokra, tendenciákra és hipotézisekre.

Noha az elemzés még bôven hagy hátra tisztázandó és megválaszolandó kérdéseket, s noha valóban érezhetünk egyfajta kiábrándultságot a szerzók részéról, Gardner és Davis mégis pozitív, lelkesítô gondolatokkal búcsúzik az olvasótól, melyek tükrözik saját, magabiztos elképzeléseiket: összességében talán a technológiai függés domborodott ki erôsebben a múben, semmint az irányítás képessége, az app-generációnak azonban nem kell elfogadnia ezeket a trendeket. Új ötletekkel előállni mindig lehetséges lesz, az előállítás és megvalósítás során pedig a technika nem szükségszerúen hátráltat, sốt, sok esetben a segítségünkre lehet. A döntés egyeloóre a humán ágens kezében van: az applikációk nem fognak eltûnni és nem is ez a cél, a kérdés sokkal inkább az: függók leszünk-e vagy irányítók, vagy esetleg meghaladjuk az applikációkat és egy új korba lépünk ?

A kötet erôsségei: a generáció biológiai definíciójának vizsgálata és összevetése újabb definíciókkal a tudatosság és a technológia kontextusában, a XX. század tömegmédia uralta világának összehasonlítása az egyre inkább jellemzố és dominánssá váló, XXI. századi digitális miliôvel, a diákok múalkotásainak longitudinális vizsgálata a digitális média és az applikációk hatásvizsgálatainak kiegészítéseképpen, valamint a vallási, etikai, oktatási dimenziók beemelése (utóbbi még kiegészítésre szorul), illetve a fiatal generációk viselkedésének három fó aspektus mentén történố vizsgálata „pszichológiai-technológiai” kontextusban: identitás, intim kapcsolatok és imaginációs erô jól körülhatárolt területei. Külön érték a minilexikon létrehozása: a média és a technológia kontribúciójának vizsgálata a viselkedésre és a tudatosságra a jelen és korábbi korszakokban (további kiegészítésre, bóvítésre szorul). 
A kötet olvasása során felmerül a kérdés: a super-app alkalmazás(a) valóban elvezet-e a boldog élethez? Véleményem szerint, a kérdés nem így, sokkal inkább úgy merül fel: lehetséges egy olyan társadalom létrejötte, amelyben minden problémára egy app ad megoldást? Elkövetkezhet-e egy olyan generáció, amelyben mindannyian felhasználók vagyunk, s ugyanakkor app-függók is? S vajon létezhet-e ez a generáció utópikus módon: oly módon, hogy az applikációk az egyének irányítása alatt és szolgálatában álljanak? De legfóképpen: mi lesz a jövő nagy felfedezése: meg lehet-e haladni az app-et? Ezekre és hasonló felvetésekre már nem térnek ki részletesen a szerzók, csupán halvány sugalmazásokkal találkozhatunk, a választ azonban egyedül - applikációk segítségével vagy éppen anélkül -, kell megtalálnunk. 